\title{
Pengaruh Risk Profile, Good Corporate Governance, Earning, Capital terhadap Value of Firm di Bursa Efek Indonesia
}

\author{
Rhevinalda Bima Prakarsa \\ Winwin Yadiati \\ Handiani Suciati \\ Akuntansi, Universitas Padjadjaran, Indonesia \\ Korespondensi penulis: rrevhin@gmail.com
}

\begin{abstract}
The purpose of the company is to increase firm value. But in the last six years, the firm value of the banking sector has fluctuated and even tends to decrease. The level of banking health can be expected to increase firm value. The level of banking health can be measured using the Risk Profile (RP), Good Corporate Governance (GCG), Earning, Capital (RGEC) method which is the latest formula after Capital, Asset Quality, Management, Earning, Liquidity (CAMEL). The purpose of this study was to determine the effect of banking health on the firm value. The research method uses partial panel data regression through the determination of the estimation model and the classical assumption test in advance using 33 banks listed on the Indonesia Stock Exchange (IDX). The results showed that there was a significant and positive effect between Return on Asset (ROA) and Capital Adequacy Ratio (CAR) on firm value. Besides, there was a positive but not significant effect between GCG and risk profile on firm value. The results showed that capital is a factor of business developer and company earning can show as a signal of quality prospects. The application of GCG is not a significant influence because the results of self-assessment are not following fraud that occurs. Banks must be able to manage their risk so that the risk can be an encouragement for them to produce high values.
\end{abstract}

Keywords: Capital; Earning; Firm value; Good Corporate Governance; Risk profile.

\begin{abstract}
Abstrak. Tujuan berdirinya perusahaan ialah meningkatkan nilai perusahaan. Namun, dalam enam tahun terakhir ini, nilai perusahaan di sektor perbankan bergerak fluktuatif, bahkan cenderung menurun. Tingkat kesehatan perbankan yang baik dapat diharapkan untuk meningkatkan nilai bagi perusahaan. Tingkat kesehatan perbankan dapat diukur dengan menggunakan metode Risk Profile (RP), Good Corporate Governance (GCG), Earning, Capital (RGEC) yang merupakan formula terbaru setelah Capital, Asset Quality, Management, Earning, Liquidity (CAMEL). Tujuan penelitian ini adalah untuk mengetahui pengaruh tingkat kesehatan perbankan terhadap nilai perusahaan. Metode penelitian yang digunakan dalam penelitian ini adalah regresi data panel secara parsial melalui penentuan model estimasi dan uji asumsi klasik terlebih dahulu menggunakan
\end{abstract}


33 sampel bank yang terdaftar di Bursa Efek Indonesia (BEI). Hasil penelitian menunjukkan bahwa ada pengaruh positif dan signifikan antara Return on Asset (ROA) dan Capital Adequacy Ratio (CAR) terhadap nilai perusahaan. Selain itu, pengaruh positif tetapi tidak signifikan antara $G C G$ dan risk profile terhadap nilai perusahaan. Hasil penelitian ini menunjukkan bahwa modal merupakan salah satu faktor pengembang bisnis dan earnings perusahaan dapat menunjukkan prospek atau sinyal yang berkualitas. Penerapan GCG tidak begitu berpengaruh, karena hasil penilaian self-assesment tidak sesuai dengan fraud yang terjadi. Selanjutnya, perbankan harus dapat mengelola risiko agar dapat menjadi dorongan bahwa bank dapat menghasilkan nilai yang tinggi.

Kata Kunci: Earning; Good Corporate Governance; Modal; Nilai perusahaan; Profil risiko.

Article Info:

Received: October 12,2019

\section{LATAR BELAKANG}

Suatu negara dalam menjalankan kegiatan ekonominya tidak terlepas dari peran penting sektor perbankan (Carillo \& Giovana, 2012), sehingga pemerintah Indonesia juga melakukan pengawasan khusus terhadap keberlangsungan sektor perbankan melalui Peraturan Bank Indonesia (PBI) dan juga Otoritas Jasa Keuangan (OJK). Salah satu regulasinya ialah tingkat kesehatan perbankan bank umum. Tingkat kesehatan perbankan dapat menjadi faktor yang dipertimbangkan oleh investor (Setyawan \& Mawardi, 2012). Peningkatan kesehatan perbankan dapat meningkatkan harga saham atau nilai perusahaan perbankan (Abdullah \& Suryanto, 2004). Theory of the Firm menjelaskan bahwa dasar tujuan pendirian suatu perusahaan adalah untuk meningkatkan nilai perusahaan (Salvatore, 2005), karena kemakmuran para pemilik saham dapat ditunjukkan melalui besaran nilai perusahaannya (Fama, 1978). Gambar 1 menunjukkan grafik nilai perusahaan (Tobins $Q$ ) pada emiten sektor perbankan yang mencatatkan namanya di Bursa Efek Indonesia (BEI).

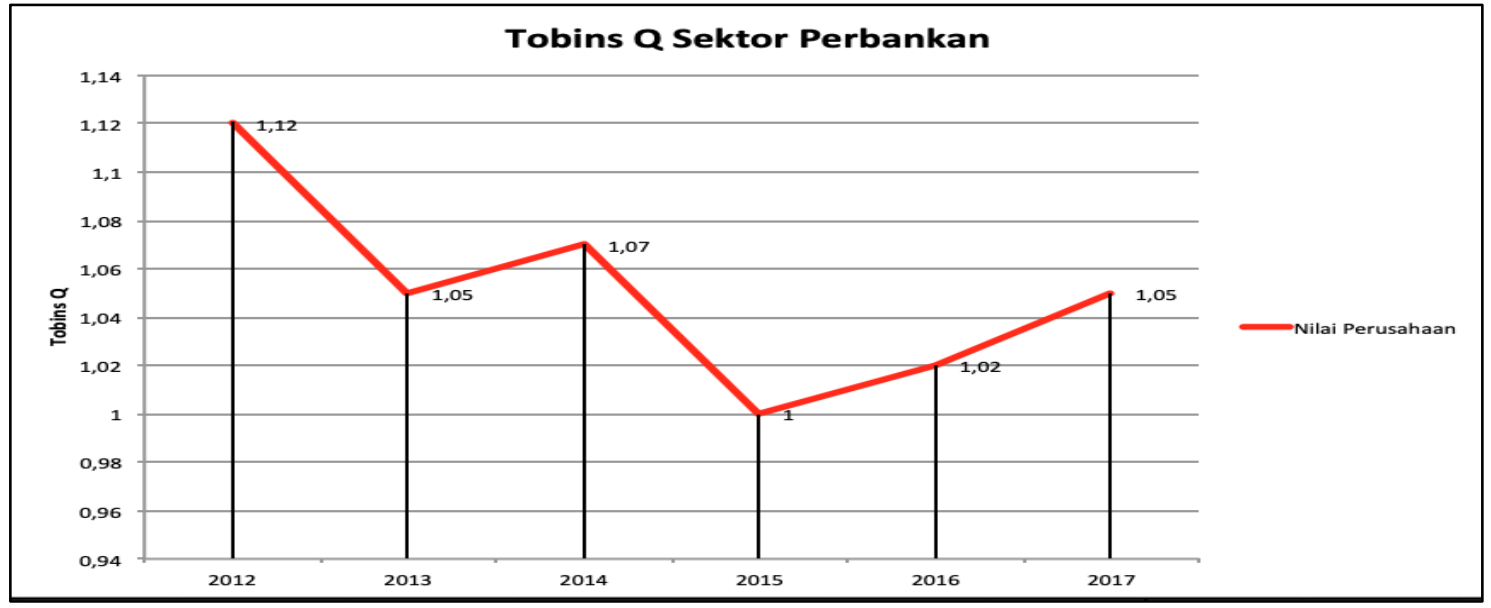

Sumber: Annual report Laporan Keuangan Perbankan 2012-2017.

Gambar 1. Grafik Tobins $Q$ Perbankan 2012-2017 
Gambar 1 menunjukkan bahwa dalam enam tahun terakhir, grafik nilai perusahaan pada sektor perbankan di Indonesia bersifat fluktuatif bahkan cenderung menurun. Tentunya ini bukan hal yang baik untuk para pemegang saham ketika nilai perusahaan yang dimiliki perusahaannya tidak menunjukkan peningkatan atau berada di bawah angka satu (Scharfenaker \& Santos, 2015; Sudiyatno \& Puspitasari, 2010). Jika melihat laporan tahunan perusahaan, setidaknya terdapat beberapa bank yang mengalami penurunan nilai perusahaan setiap tahunnya. Bahkan, beberapa bank tidak pernah memiliki nilai Tobins $Q$ di atas angka satu dalam enam tahun terakhir. Keberhasilan bisnis perbankan dapat dilihat pada pengukuran yang akurat dan tingkat efisiensi yang baik pada pengelolaan risikonya (Gieseche, 2004). Laporan tahunan perbankan Otoritas Jasa Keuangan (OJK) pada tahun 2014 menunjukkan bahwa pada tahun 2013 hingga 2014 terdapat 1.616 pengaduan perbankan, yaitu $57,79 \%$ berasal dari pemberian kredit, kemudian diikuti dengan masalah dana pihak ketiga sebesar 16,75\%.

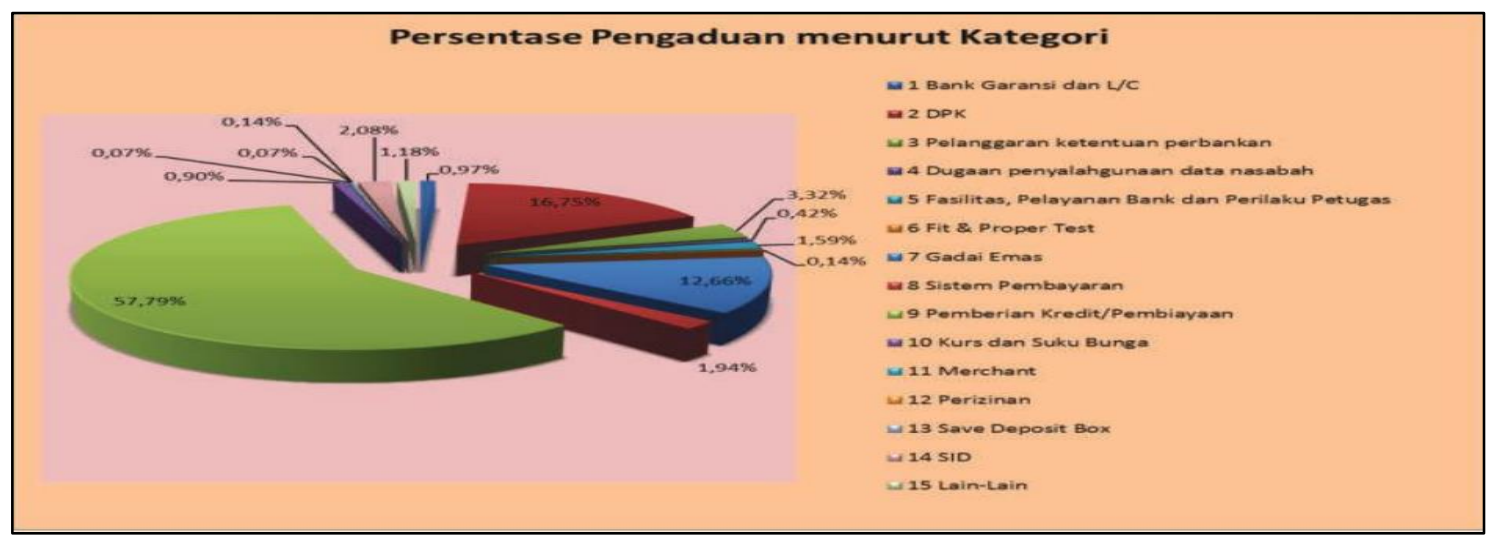

Sumber: Laporan tahunan perbankan OJK tahun 2015.

\section{Gambar 2. Persentase Pengaduan Menurut Kategori}

Laporan tahunan perbankan OJK tahun 2015 menunjukkan terjadinya kerugian senilai Rp7.701.615.936.801 akibat fraud (Gambar 2). Bahkan, pada periode tahun 2014 hingga 2016, ada 108 kasus kejahatan yang ditindak (CNN Indonesia, 2016). Jika Risiko tinggi, perusahaan seharusnya dapat meminimalisir risiko tersebut untuk menjaga kepercayaan nasabah. Tingginya jumlah fraud tidak sebanding dengan hasil penilaian GCG. Dalam kurun waktu tahun 2012-2018, rata-rata GCG sektor perbankan selalu berada dalam keadaan baik. Kerugian akibat terjadinya fraud dapat menjadi penyebab menurunnya rata-rata nilai perusahaan, tetapi penerapan GCG yang baik oleh perbankan seharusnya dapat meminimalisir fraud, sehingga nilai perusahaan dapat meningkatkan (Renders \& Gaeremynck, 2012; Garay \& Gonzales, 2008).

Tujuan penelitian ini adalah memahami dampak penerapan GCG terhadap nilai perusahaan. Ketika GCG dapat diaplikasikan dengan baik, maka hal itu akan memberikan dampak positif pada nilai perusahaan (Bauer, Guenster, \& Otten, 2004). Komponen lain dalam tingkat kesehatan perbankan adalah earning dan capital perusahaan. Peneliti lainnya menyimpulkan adanya pengaruh antara earning terhadap nilai perusahaan (Hidayat, 2014; O’Sullivan dan McCallig, 2012; Cho \& Pucik, 2005; Hendrayana \& Yasa, 2015). Namun, jika melihat laporan tahunan perusahaan kondisi ROA yang baik belum tentu menunjukkan nilai perusahaan yang baik begitu pun hasil ROA yang 
kurang baik belum tentu menunjukkan nilai perusahaan buruk seperti ditunjukkan pada Gambar 3.

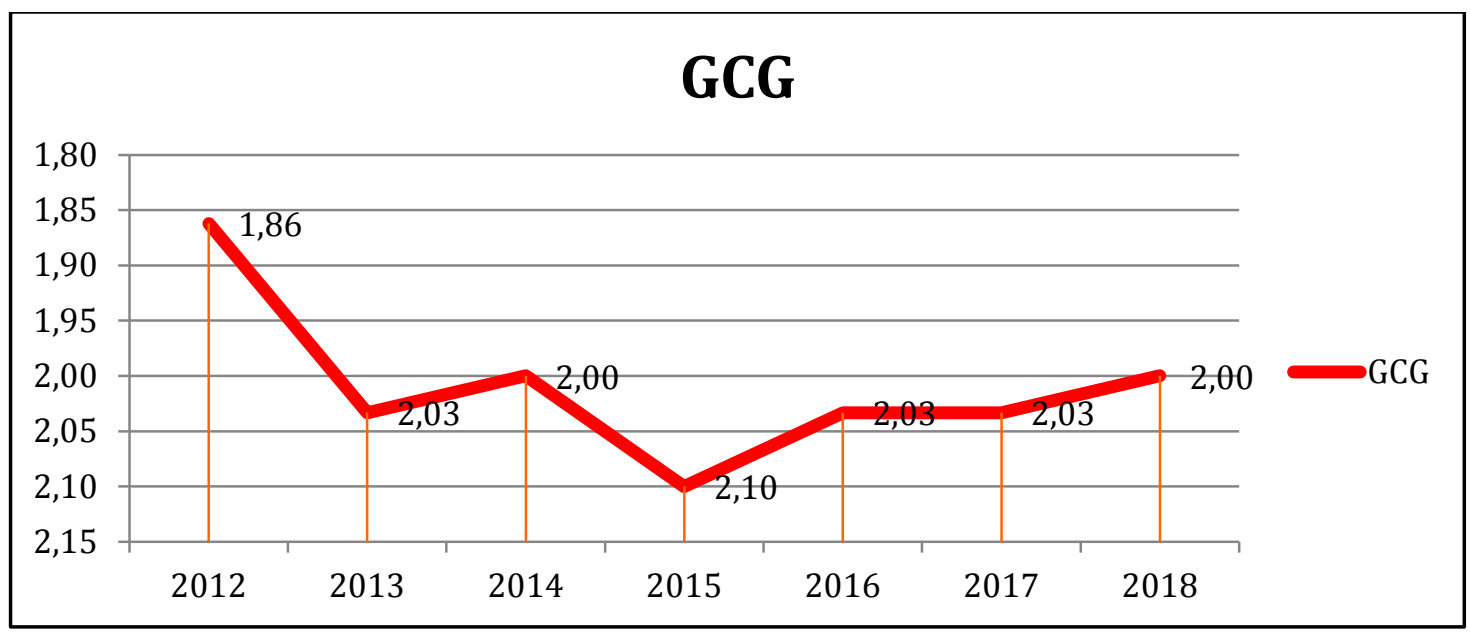

Sumber: Annual Report Perbankan 2012-2018.

Gambar 3. Grafik Self-assesment GCG Perbankan di Indonesia Tahun 2012-2018

Penelitian sebelumnya menunjukkan bahwa ketika rasio CAR meningkat, maka kondisi itu akan diikuti peningkatan nilai perusahaan (Abdulazeez, Saif-Alyousfi, Saha, \& Rohani, 2017; Nasser \& Djadjang, 2005; Murni \& Sabijono, 2018; Sulastiningsih \& Sholihati, 2018; Widati, 2012; Hidayat, 2014; Sasongko \& Susilawati, 2017; Naftali Saerang, \& Tulung, 2018). Hingga pertengahan tahun 2019, perbankan di Indonesia memiliki nilai CAR paling tinggi di Asia (Kontan.co.id, 2019). Namun, nilai perusahaan perbankan di Indonesia bergerak fluktuatif. Berdasarkan fenomena tersebut, penelitian mengenai pengaruh tingkat kesehatan perbankan terhadap nilai perusahaan di Indonesia ini perlu dilakukan.

\section{KAJIAN TEORITIS}

\section{Nilai Perusahaan}

Menurut theory of the firm, ada dua tujuan perusahaan, yaitu memaksimalkan kekayaan dan nilai perusahaan (Salvatore, 2005). Pada dasarnya, tujuan pengelolaan keuangan perusahaan ialah untuk memakmurkan pemegang saham melalui peningkatan nilai perusahaannya (Fama, 1978; Salvatore, 2005). Hal tersebut yang mendasari pemikiran bahwa pihak manajemen berkewajiban untuk bekerja demi peningkatan kemakmuran pemilik perusahaan (Mardiati, Nazir, \& Putri, 2012; Brigham \& Gapenski, 2006). Nilai perusahaan menjadi pandangan bagi investor terhadap kesuksesan yang berkaitan dengan harga saham perusahaan tersebut (Sujono \& Soebiantoro, 2007).

\section{Tobin's $Q$}

Mengukur nilai perusahaan dapat dilakukan dengan beberapa rasio. Salah satunya adalah $Q$ Ratio atau biasanya disebut Tobin's $Q$ (Tobin, 1967). Tobin's $Q$ diyakini dapat memberikan informasi terbaik, karena rasio ini melibatkan semua unsur modal saham dan hutang yang dimiliki perusahaan, bukan hanya saham biasa atau pun ekuitas perusa- 
haan saja. Aset perusahaan secara keseluruhan pun turut menjadi perhitungan. Ketika market value aset perusahaan membesar, maka investor semakin bersedia untuk mengeluarkan dana modal yang lebih untuk memiliki perusahaan tersebut, jika dibandingkan dengan book value aset perusahaan (Sukamulja, 2004).

\section{Agency Theory}

Agency theory adalah munculnya risiko konflik kepentingan di antara pihak yang memiliki kepentingan di dalam perusahaan dan menghasilkan agency problem (Jensen \& Warner, 1988). Penanganan agency problem pada perusahaan perlu ditangani dengan menerapkan prinsip GCG (Retno \& Priantinah, 2012). Upaya untuk meminimalkan masalah keagenan juga harus disertai dengan penerapan manajemen risiko. Manajemen risiko merupakan salah satu strategi perbankan untuk mencapai tujuan perusahaan (Ikatan Bankir Indonesia, 2018). Penerapan GCG dan tata kelola manajemen risiko ini sudah diatur di dalam PBI (Peraturan Bank Indonesia), yaitu kedua sistem tersebut termasuk di dalam penilaian tingkat kesehatan perbankan.

\section{Tingkat Kesehatan Perbankan}

Menurut PBI nomor 13/1/PBI/2011, tingkat kesehatan perbankan merupakan hasil dari penilaian kondisi perbankan yang dilakukan terhadap risiko dan kinerjanya. Pada dasarnya, kegiatan bisnis perbankan seperti tingkat kesehatan bank, keberlangsungan usaha, dan pengelolaan bank merupakan tanggung jawab pihak pengelola perbankan. Oleh karena itu, perbankan harus mampu meningkatkan dan memelihara tingkat kesehatan perbankan dengan menerapkan risk management, termasuk di dalamnya melakukan self-assesment secara berkala. Tahun 2011, Bank Indonesia (BI) mengeluarkan aturan baru mengenai penilaian tingkat kesehatan perbankan dengan menerbitkan PBI nomor 13/1/PBI/2011 yang mengganti formula CAMEL (Capital, Asset Quality, Management, Earning, Liquidity) dengan formula RGEC (Risk Profile, Good Corporate Governance, Earning, Capital) untuk mengukur tingkat kesehatan perbankan.

\section{Profile Risiko terhadap Nilai Perusahaan}

Risiko merupakan suatu kondisi ketidakpastian yang dapat merugikan dan menghalangi pencapaian tujuan perusahaan. Beberapa macam risiko, seperti risiko kredit yang tinggi dapat menjadi penyebab sulitnya perbankan dalam menyalurkan kredit, sedangkan kegiatan bisnis perbankan tidak luput dari pemberian kredit kepada nasabah (Sentausa, 2009) dan risiko pasar yang berada di luar kendali perbankan juga berpotensi merugikan posisi portofolio bank (Ikatan Bankir Indonesia, 2018). Manajemen risiko merupakan salah satu strategi perbankan untuk meminimalisir risiko yang dihadapi perbankan, sehingga perbankan dapat mencapai tujuannya, yaitu meningkatkan nilai perusahaan (Ikatan Bankir Indonesia, 2018). Berdasarkan uraian tersebut, hipotesis kesatu dirumuskan sebagai berikut:

$\mathbf{H}_{1}$ : Terdapat pengaruh negatif Risk Profile terhadap Nilai Perusahaan.

\section{GCG terhadap Nilai Perusahaan}

Konflik kepentingan perlu diarahkan pada pengontrolan perilaku manajer untuk melindungi hak-hak pemegang saham. Beberapa peneliti berpendapat bahwa penerapan konsep GCG dapat mengurangi agency problem, sehingga perusahaan dapat mecapai tujuannya, yaitu meningkatkan nilai perusahaan (Astrini, Biekayanti, \& Suhardjanto, 
2015; Tjager, 2003). Beberapa penelitian sebelumnya menunjukkan bahwa GCG yang diterapkan dengan baik dapat menghasilkan dampak yang lebih baik pula bagi nilai perusahaan (Bauer et al., 2004). Berdasarkan uraian tersebut, hipotesis kedua dirumuskan sebagai berikut:

$\mathbf{H}_{2}$ : Terdapat pengaruh positif $G C G$ terhadap Nilai Perusahaan.

\section{ROA terhadap Nilai Perusahaan}

Earning merupakan gambaran kinerja manajemen dalam mengelola suatu perusahaan. Semakin tinggi earning merupakan indikator prospek perusahaan yang berkualitas semakin baik, sehingga pasar akan merespon positif sinyal tersebut dan nilai perusahaan akan meningkat pula (Sujono \& Soebiantoro, 2007). Berdasarkan uraian tersebut, hipotesis ketiga dirumuskan sebagai berikut:

$\mathbf{H}_{3}$ : Semakin tinggi ROA, maka nilai perusahaan akan semakin tinggi.

\section{CAR terhadap Nilai Perusahaan}

Peranan modal sangat penting bagi operasi perusahaan, sehingga kegiatan operasional bank dapat berjalan dengan lancar apabila ia memiliki modal yang cukup (Kasmir, 2008). Modal juga merupakan faktor penggerak utama dalam pengembangan usaha (Naceur \& Goaied, 2008). CAR berfungsi agar para deposan yang menyimpan uang di bank merasa tenang bahwa uang yang mereka simpan terjamin dan dapat dikembalikan tepat waktu (Ikatan Bankir Indonesia, 2018). Semakin tinggi CAR, maka para deposan semakin yakin untuk menyimpan uang mereka di bank. Semakin tinggi CAR, maka semakin besar pula sumber daya finansial bank, sehingga kemampuan tersebut dapat memperlancar kegiatan usaha bank untuk mencapai tujuannya. Berdasarkan uraian tersebut, hipotesis keempat dirumuskan sebagai berikut:

$\mathbf{H}_{4}$ : Semakin tinggi CAR, maka nilai perusahaan akan semakin tinggi.

Hubungan antarvariabel dalam penelitian ini ditunjukkan pada model penelitian yang disajikan pada Gambar 4.

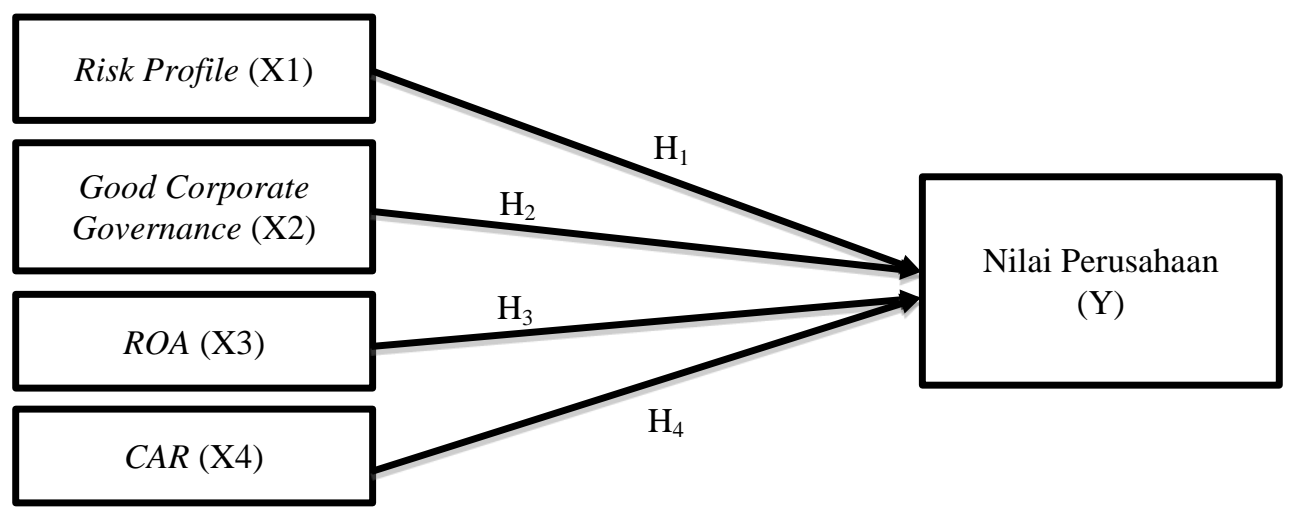

Sumber: Peraturan Bank Indonesia PBI nomor 13/1/PBI/2011, POJK Nomor 4/POJK.03/2016, Ikatan Bankir Indonesia (2018), dan Corporate Governance Perception Index (2008).

\section{Gambar 4. Skema Kerangka Penelitian}




\section{METODE PENELITIAN}

Penelitian ini merupakan penelitian kuantitatif bersifat asosiatif, yaitu penelitian yang mempunyai tujuan untuk mencari tahu hubungan antara variabel bebas dan variabel terikat (Gunawan, 2016). Hipotesis dalam penelitian ini diuji menggunakan uji parsial (t-test) untuk mengetahui pengaruh antarvariabel. Metode analisis data yang digunakan adalah analisis regresi data panel dengan melakukan penentuan model estimasi dan uji asumsi klasik terlebih dahulu. Persamaan regresi data panel ditunjukkan pada persamaan [1].

$$
Y=\beta_{0}+\beta_{1} X_{1}+\beta_{2} X_{2}+\beta_{3} X_{3}+\beta_{4} X_{4}+\varepsilon
$$

Y merupakan variabel dependen nilai perusahaan, $\beta_{0}$ merupakan konstanta, dan $\mathrm{X}_{1}$ hingga $\mathrm{X}_{4}$ adalah variabel independen Risk Profile, GCG, Earning, dan Capital, sedangkan $\beta_{1}, \beta_{2}, \beta_{3}$, dan $\beta_{4}$ merupakan koefisien regresi, serta $\varepsilon$ adalah variabel pengganggu di luar persamaan RGEC.

\section{Data dan Sampel}

Data penelitian ini menggunakan data kuantitatif seperti data rasio dari laporan tahunan perusahaan dan juga data ordinal di dalam laporan tata kelola perusahaan dan profil risiko. Penelitian ini menggunakan data sekunder yang diperoleh dari annual report yang sudah diaudit dan telah dipublikasikan oleh perusahaan sampel pada tahun 2013 hingga 2019. Penentuan data dimulai dari tahun 2013 atas dasar PBI No. 13/1/PBI/2011 yang mulai efektif digunakan pada tahun 2012 oleh perbankan di Indonesia. Sampel penelitian berjumlah 33 perusahaan menggunakan laporan tahunan perbankan untuk periode tahun 2013 hingga 2019.

\section{Variabel Independen}

\section{Risk Profile}

Berdasarkan Peraturan Otoritas Jasa Keuangan RI nomor 17/POJK.03/2014, risiko yang wajib dikelola oleh manajemen risiko terintegrasi mencakup delapan jenis risiko, yaitu risiko kredit, risiko pasar, risiko likuiditas, risiko operasional, risiko hukum, risiko reputasi, risiko stratejik, dan risiko kepatuhan. Surat Edaran OJK RI nomor 14/ SEOJK.03/2017 memaparkan lebih jelas mengenai peringkat faktor profil risiko yang terdiri atas lima peringkat seperti ditunjukkan pada Tabel 1.

Tabel 1. Kualitas Manajemen Risiko Perbankan di Indonesia

\begin{tabular}{lccccc}
\hline \multirow{2}{*}{ Risk Profile } & \multicolumn{5}{c}{ Kualitas Penerapan Manajemen Risiko } \\
& Strong & Satisfactory & Fair & Marginal & Unsatisfactory \\
\hline Low & 1 & 1 & 2 & 3 & 3 \\
\hline Low to Moderate & 1 & 2 & 2 & 3 & 4 \\
\hline Moderate & 2 & 2 & 3 & 4 & 4 \\
\hline Moderate to High & 2 & 3 & 4 & 4 & 5 \\
\hline High & 3 & 3 & 4 & 5 & 5 \\
\hline
\end{tabular}

Sumber: SE OJK No.14/SEOJK.03/2017.

\section{Good Corporate Governance (GCG)}

Menurut SK BI No. 9/12/DPNP, penilaian GCG dapat dilakukan dengan cara self- 
assestment. Penilaian self-assetment ini mengacu pada POJK RI No. 55/POJK.03/2016 dan POJK RI nomor 14/SEOJK.03/2017. Peraturan tersebut membagi peringkat faktor keberhasilan penerapan tata kelola perusahaan ke dalam lima peringkat. Peringkat tata kelola perusahaan dengan angka yang lebih kecil mencerminkan penerapan tata kelola yang lebih baik, seperti yang diperlihatkan pada Tabel 1.

\section{Return on Asset (ROA)}

Menurut SE OJK RI nomor 14/SEOJK.03/2017, faktor rentabilitas dinilai dengan mengevaluasi kinerja dan sumber rentabilitas, kesinambungan rentabilitas, dan manajemen rentabilitas. Penelitian ini menggunakan ROA untuk mengukur rentabilitas. Di dalam SE OJK RI nomor 14/SEOJK.03/2017 menentukan hanya indikator ROA yang memasukkan seluruh aktiva perbankan. Formula perhitungan ROA (Kasmir, 2008) dituangkan pada persamaan [2].

$$
\text { ROA }=\frac{\text { Laba Bersih }}{\text { Total Assets }} \times 100 \%
$$

\section{Capital}

Berdasarkan SE OJK RI No. 14/SEOJK.03/2017, modal dapat diukur dengan menggunakan CAR. Beberapa peneliti menggunakan variabel CAR seperti Abdullah \& Suryanto (2004); Pramana dan Artini (2016); Indiani dan Dewi (2016); serta Cholifah dan Suhadak (2017). Formula perhitungan CAR (Kasmir, 2008) ditampilkan pada persamaan [3].

$$
C A R=\frac{\text { Modal Bank }}{A T M R} \times 100 \%
$$

\section{Variabel Dependen}

Penelitian ini menggunakan nilai perusahaan yang diukur dengan Tobins $Q$ sebagai variabel dependen. Formula Tobins $Q$ (Tobin, 1967) dijabarkan pada persamaan [4].

$$
\text { Tobins } Q=\frac{\text { Total Market Value of Firm }}{\text { Total Asset Value }}
$$

\section{HASIL DAN PEMBAHASAN}

\section{Kondisi Tingkat Kesehatan Perbankan}

Hasil rata-rata tingkat kesehatan perbankan di Indonesia menunjukkan hasil yang baik. Kondisi ini dapat dilihat pada Tabel 2. Risk Profile (RP) pada perbankan di Indonesia menunjukkan nilai yang baik. Bahkan, dalam kurun waktu tujuh tahun terakhir, hanya emiten BEKS (PT Bank Pembangunan Daerah Banten, Tbk.) saja yang pernah mengalami peringkat 4, yaitu memiliki kondisi risiko yang kurang baik. Di samping itu, hanya emiten BCIC (PT Bank Jtrust Indonesia, Tbk.) dan BABP (PT Bank MNC Internasional, Tbk.) yang sempat memiliki nilai GCG dalam kategori tidak baik. ROA perbankan banyak yang memiliki nilai tidak stabil. Bahkan, hanya bank BUKU 1 (bank yang memiliki modal inti kurang dari satu triliun rupiah), BBMD (PT Bank Mestika Dharma, Tbk.), BMAS (Bank Maspion Indonesia, Tbk.) dan BNBA (PT Bank Bumi Arta, Tbk.) yang memiliki nilai ROA stabil dengan kategori sangat baik, serta seluruh CAR perbankan menunjukkan hasil yang tinggi. 
Tabel 2. Rata-rata Komponen Tingkat Kesehatan Perbankan Periode Tahun 2013-2019

\begin{tabular}{ccccc}
\hline Tahun & RP & ROA & GCG & CAR \\
\hline 2013 & 2,03 & 2,13 & 1,97 & 18,08 \\
\hline 2014 & 2,06 & 1,93 & 2,06 & 19,13 \\
\hline 2015 & 2,12 & 1,43 & 2,00 & 18,75 \\
\hline 2016 & 2,06 & 0,36 & 2,09 & 18,72 \\
\hline 2017 & 2,09 & 1,64 & 2,06 & 20,67 \\
\hline 2018 & 2,03 & 1,58 & 2,03 & 20,28 \\
\hline 2019 & 2,09 & 1,36 & 2,00 & 21,01 \\
\hline
\end{tabular}

Sumber: Data diolah (2019).

\section{Hasil Pengujian Data Panel dan Asumsi Klasik}

Ada tiga metode dalam pendekatan estimasi, yaitu model Pool Least Square-OLS (Common), model Fixed Effect, dan model Random Effect.

\section{Uji Chow (Likelihood Ratio)}

Berdasarkan pengujian model Fixed Effect, data hasil pengujian dalam penelitian ini disajikan pada Tabel 3.

Tabel 3. Hasil Uji Chow

\begin{tabular}{ccccc}
\hline Variabel & Effect Test & Statistic & Prob & Keputusan \\
\hline Risk Profile (RP) & Cross-section F & 2,927241 & 0,0000 & Fixed Effect \\
GCG & Cross-section $\mathrm{F}$ & 2,811980 & 0,0000 & Fixed Effect \\
\hline ROA & Cross-section $\mathrm{F}$ & 3,100215 & 0,0000 & Fixed Effect \\
\hline CAR & Cross-section $\mathrm{F}$ & 2,165294 & 0,0014 & Fixed Effect \\
\hline
\end{tabular}

Sumber: Data diolah (2019).

Tabel 2 menunjukkan hasil Prob ( $p$-value) cross-section F untuk variabel Risk Profile, GCG, dan ROA sebesar 0,0000 dan cross-section F untuk variabel CAR 0,0014. Hasil ini menunjukkan bahwa Probability ( $p$-value) cross-section $\mathrm{F}<0,05$, maka $\mathrm{H}_{0}$ ditolak, sehingga model yang digunakan untuk seluruh variabel adalah fixed effect. Karena keputusan yang diperoleh menggunakan fixed effect, maka data penelitian harus dilakukan tahapan pengujian berikutnya, yaitu uji Hausman.

\section{Uji Hausman}

Berdasarkan pengujian model Random Effect, data hasil pengujian dalam penelitian ini ditunjukkan pada Tabel 4.

Tabel 4. Hasil Uji Hausman

\begin{tabular}{cccc}
\hline Variabel & Test Summary & Prob & Keputusan \\
\hline Risk Profile (RP) & Cross-section Random & 0,9115 & Random Effect \\
GCG & Cross-section Random & 0,8387 & Random Effect \\
\hline ROA & Cross-section Random & 0,1989 & Random Effect \\
\hline CAR & Cross-section Random & 0,4906 & Random Effect \\
\hline
\end{tabular}

Sumber: Hasil output Eviews 9. 
Tabel 4 menunjukkan bahwa hasil probability ( $p$-value) cross-section random sebesar 0,9115 untuk variabel Risk Profile, 0,8387 untuk variabel GCG, 0,1989 untuk variabel ROA, dan 0,4906 untuk variabel CAR. Atas dasar hasil ini, maka model random effect dapat dikatakan lebih baik daripada model fixed effect. Setelah melakukan uji Hausman, maka tahapan selanjutnya ialah pengujian antara metode common effect dan random effect menggunakan uji Lagrange Multiplier yang berfungsi untuk mengetahui lebih pasti apakah random effect dapat digunakan dalam penelitian ini.

\section{Uji Lagrange Multiplier}

Tabel 5 memperlihatkan bahwa hasil probabilitas Breusch-Pagan (BP) untuk variabel Risk Profile, GCG, dan ROA sebesar 0,0000 dan variabel CAR sebesar 0,0009. Hasil ini menunjukkan bahwa seluruh variabel memiliki nilai probabilitas ( $p$-value $)<$ 0,05 hasil ini menunjukkan bahwa bahwa $\mathrm{H} 0$ ditolak atau seluruh penelitian ini akan menggunakan metode random effect.

Tabel 5. Hasil Uji Lagrange Multiplier

\begin{tabular}{cccccc}
\hline Variabel & & $\begin{array}{c}\text { Cross } \\
\text { Section }\end{array}$ & $\begin{array}{c}\text { Test Hypothesis } \\
\text { Time }\end{array}$ & Both & \multirow{2}{*}{ Keputusan } \\
\hline Risk & Breusch-Pagan & 25,45753 & 0,935417 & 26,39294 & \multirow{2}{*}{ Random Effect } \\
Profile & $(\mathrm{BP})$ & $(0,0000)$ & $(0,3335)$ & $(0,0000)$ & \\
\hline \multirow{2}{*}{ GCG } & Breusch-Pagan & 24,78947 & 0,262816 & 25,05229 & Random Effect \\
& $(\mathrm{BP})$ & $(0,0000)$ & $(0,6082)$ & $(0,0000)$ & \\
\multirow{2}{*}{ ROA } & Breusch-Pagan & 25,16496 & 28,32859 & 53,49355 & \multirow{2}{*}{ Random Effect } \\
& $(\mathrm{BP})$ & $(0,0000)$ & $(0,0000)$ & $(0,0000)$ & \\
\multirow{2}{*}{ CAR } & Breusch-Pagan & 11,05846 & 3,299094 & 14,35756 & \multirow{2}{*}{ Random Effect } \\
& $(\mathrm{BP})$ & $(0,0009)$ & $(0,0693)$ & $(0,0002)$ & \\
\hline
\end{tabular}

Sumber: Hasil output Eviews 9.

Seluruh variabel yang digunakan di dalam penelitian ini menggunakan ketiga tahap uji model. Dari hasil pengujian tersebut, seluruh variabel disimpulkan dapat menggunakan metode random effect. Hasil uji asumsi klasik menunjukkan bahwa data yang digunakan berdistribusi normal, tidak terdapat masalah autokorelasi, dan tidak terdapat masalah heteroskedastisitas.

\section{Hasil Uji Regresi}

\section{Uji Regresi Risk Profile terhadap Nilai Perusahaan}

Hasil estimasi regresi data panel untuk Risk Profile ditunjukkan pada Tabel 6.

Tabel 6. Hasil Estimasi Risk Profile terhadap Nilai Perusahaan

\begin{tabular}{ccccc}
\hline Variabel & Koefisien & Std. Error & t-Statistic & Prob. \\
\hline C & 0,609667 & 0,049879 & 12,22296 & 0,0000 \\
RP & 1,321785 & 2,366076 & 0,558640 & 0,5771 \\
\hline
\end{tabular}

Sumber: Data diolah (2019).

Hasil yang ditunjukkan pada Tabel 6 diartikan sebagai berikut:

- C sebesar 0,609667 dapat diartikan bahwa apabila RP bernilai nol, maka nilai perusahaan adalah 0,609667 satuan. 
- Nilai probabilitas menunjukkan nilai 0,5771. Hasil ini menunjukkan bahwa tingkat signifikansi lebih dari 0,05 sehingga bahwa tidak ada pengaruh negatif Risk Profile terhadap nilai perusahaan.

\section{Pengujian Hipotesis Risk Profile terhadap Nilai Perusahaan (Uji Parsial)}

Berdasarkan Tabel 6, nilai p-value variabel RP sebesar 0,5771. Jika menggunakan alpha 5\%, maka $p$-value RP lebih besar dari 0,05 atau $0,5771>0,05$, sehingga $\mathrm{H}_{1}$ diterima. Artinya, tidak ada pengaruh negatif Risk Profile terhadap nilai perusahaan. Hasil penelitian ini sesuai dengan penelitian Fauziah, Iskandar, Paminto, dan Ulfah (2019), Wiagustini dan Permatawati (2015), dan Saraswathi, Wiksuana, dan Rahyuda (2016). Hal ini dapat terjadi karena pada kenyataannya terdapat bank yang memiliki risiko tinggi, tetapi bank tersebut memiliki nilai perusahaan yang cukup baik, seperti BCIC (PT Bank Jtrust Indonesia, Tbk.), BSWD (PT Bank of India Indonesia, Tbk.), dan BBKP (PT Bank Bukopin, Tbk.) yang memiliki nilai perusahaan baik walaupun memiliki risiko kredit yang tinggi. Hasil ini juga menunjukkan bahwa risiko likuiditas atau Loan to Deposit Ratio (LDR) yang dikelola perbankan memiliki feedback yang baik bagi nilai perusahaan, karena semakin tinggi risiko likuiditas menunjukkan bahwa kredit yang diberikan perbankan semakin besar, sehingga hal itu dapat meningkatkan pendapatan melalui kredit yang disalurkan.

\section{Uji Regresi GCG terhadap Nilai Perusahaan}

Hasil estimasi regresi data panel untuk GCG ditunjukkan pada Tabel 7.

Tabel 7. Hasil Estimasi GCG terhadap Nilai Perusahaan

\begin{tabular}{crrrr}
\hline Variabel & \multicolumn{1}{c}{ Koefisien } & \multicolumn{1}{c}{ Std. Error } & \multicolumn{1}{l}{ t-Statistic } & \multicolumn{1}{l}{ Prob. } \\
\hline C & 0,666025 & 0,049408 & 13,48013 & 0,0000 \\
GCG & 1,052432 & 0,810999 & 1,297698 & 0,1958 \\
\hline
\end{tabular}

Sumber: Data diolah (2019).

Hasil pada Tabel 7 diartikan sebagai berikut:

- C sebesar 0,666025 diartikan bahwa apabila GCG bernilai nol, maka nilai perusahaan mencapai 0,666025 satuan.

- Nilai probabilitas menunjukkan angka 0,1958. Hasil ini dapat diartikan bahwa tingkat signifikansi lebih dari 0,05, sehingga tidak ada pengaruh GCG terhadap nilai perusahaan.

\section{Pengujian Hipotesis GCG terhadap Nilai Perusahaan (Uji Parsial)}

Berdasarkan Tabel 7, nilai $p$-value variabel GCG sebesar 0,1958. Karena menggunakan alpha 5\%, maka $p$-value lebih besar dari 0,05 atau 0,1958>0,05, sehingga $\mathrm{H}_{2}$ diterima, artinya tidak ada perngaruh GCG terhadap nilai perusahaan. Hasil ini dapat terjadi karena adanya ketidaksesuaian antara mayoritas hasil self-assesment GCG perbankan dengan masalah internal/eksternal perbankan, bahkan fraud yang ada di dalam pelaksanaannya. Latar belakang penelitian ini menyebutkan bahwa dalam periode tahun 2014 hingga 2016 terdapat 108 kasus kejahatan yang ditindak oleh OJK (CNN Indonesia, 2016) dan di dalam laporan perbankan OJK menunjukkan bahwa sektor perbankan sempat mengalami beberapa kerugian yang cukup besar karena adanya fraud yang salah satunya terjadi pada tahun 2015 dan memberikan dampak kerugian mencapai Rp7.701.615.936.801. Hal tersebut sangat berkebalikan dengan hasil GCG yang didapatkan oleh mayoritas perbankan. Dari hasil ini, faktor internal seperti penerapan GCG 
tidak berpengaruh secara signifikan terhadap nilai perusahaan karena hasil penelitian ini mendukung fenomena yang terjadi, tetapi tidak sesuai dengan hasil penilaian selfassesment GCG perbankan.

\section{Uji Regresi ROA terhadap Nilai Perusahaan}

Hasil estimasi regresi data panel untuk ROA disajikan pada Tabel 8.

Tabel 8. Hasil Estimasi ROA terhadap Nilai Perusahaan

\begin{tabular}{crrrr}
\hline Variabel & Koefisien & Std. Error & \multicolumn{1}{c}{ t-Statistic } & \multicolumn{1}{c}{ Prob. } \\
\hline C & 0,855643 & 0,198975 & 4,300245 & 0,0000 \\
ROA & 0,228059 & 0,128627 & 1,773020 & 0,0779 \\
\hline
\end{tabular}

Sumber: Data sekunder yang diolah (2019).

Hasil pada Tabel 8 diartikan sebagai berikut:

- C sebesar 0,855643 yang berartia apabila ROA bernilai nol, maka nilai perusahaan akan bernilai 0,855643 satuan.

- $\beta_{1}$ menunjukkan koefisien regresi ROA yaitu sebesar 0,228059 yang berarti jika terjadi perubahan kenaikan ROA sebesar 1 satuan (dengan asumsi variabel lain konstan), maka nilai perusahaan akan mengalami peningkatan sebesar 0,228059 satuan.

\section{Pengujian Hipotesis ROA terhadap Nilai Perusahaan (Uji Parsial)}

Berdasarkan Tabel 8, nilai $p$-value variabel ROA sebesar 0,0779. Jika menggunakan alpha 5\%, maka $p$-value lebih besar dari 0,05 atau 0,0779>0,05. Namun, jika menggunakan alpha 10\%, maka p-value lebih kecil dari 0,1 atau 0,0779<0.1, sehingga $\mathrm{H}_{3}$ ditolak, artinya ROA berpengaruh positif terhadap nilai perusahaan. Hasil penelitian ini sejalan dengan penelitian Cho dan Pucik (2005); Hidayat (2014); O'Sullivan dan McCallig (2012); Saraswathi et al. (2016); Hendrayana dan Yasa (2015); serta Varaiya dan Kerin (1987).

\section{Uji Regresi CAR terhadap Nilai Perusahaan}

Hasil estimasi regresi data panel untuk CAR ditunjukkan pada Tabel 9.

Tabel 9. Hasil Estimasi CAR terhadap Nilai Perusahaan

\begin{tabular}{ccccc}
\hline Variabel & Koefisien & Std. Error & t-Statistic & Prob. \\
\hline C & 0,561464 & 0,035059 & 16,01505 & 0,0000 \\
CAR & 1,040600 & 0,378786 & 2,747199 & 0,0066 \\
\hline
\end{tabular}

Sumber: Data sekunder yang diolah (2019).

Hasil pada Tabel 8 diartikan sebagai berikut:

- C sebesar 0,561464 yang berarti apabila CAR bernilai nol, maka nilai perusahaan akan bernilai 0,561464 satuan.

- $\quad \beta_{1}$ menunjukkan koefisien regresi CAR yaitu sebesar 1,040600 yang berarti jika terjadi perubahan kenaikan CAR sebesar 1 satuan (dengan asumsi variabel lain konstan), maka nilai perusahaan akan mengalami peningkatan sebesar 1,040600 satuan.

\section{Pengujian Hipotesis CAR terhadap Nilai Perusahaan (Uji Parsial)}

Berdasarkan Tabel 9, nilai $p$-value variabel CAR sebesar 0,0066. Jika menggunakan alpha 5\%, maka p-value lebih kecil dari 0,05 atau 0,0066<0,05, sehingga $\mathrm{H}_{4}$ 
ditolak, artinya CAR berpengaruh positif terhadap nilai perusahaan. Hasil penelitian ini sesuai dengan beberapa peneliti sebelumnya, seperti Sabijono (2018), Sulastiningsih dan Sholihati (2018), Widati (2012), Hidayat (2014), Sasongko dan Susilawati (2017), dan Naftali et al., (2018). Dari hasil ini, maka dapat disimpulkan bahwa modal (Capital) merupakan faktor penggerak utama pengembangan usaha, karena dengan modal yang cukup perusahaan dapat mengembangkan usahanya (Naceur et al., 2008). Kegiatan operasional bank juga dapat berjalan dengan lancar ketika bank memiliki kecukupan modal (Kasmir, 2008), sehingga semakin tinggi rasio CAR, maka para deposan semakin yakin untuk menyimpan uang di bank, karena semakin tinggi CAR, semakin besar pula sumber daya finansial yang dapat digunakan untuk keperluan pengembangan usaha bank, sehingga bank dapat memperlancar kegiatan usaha untuk mencapai tujuan perusahaan di masa mendatang, yaitu meningkatkan nilai perusahaan.

\section{KESIMPULAN DAN SARAN}

Risk Profile tidak memiliki pengaruh negatif terhadap nilai perusahaan. Hasil penelitian ini dapat disimpulkan bahwa perbankan harus dapat mengelola risiko dengan baik, sehingga risiko tersebut dapat menjadi dorongan bagi perbankan untuk meningkatkan nilai perusahaan. Nilai risk profile dapat menjadi hal yang baik bagi nilai perusahaan, karena sektor perbankan memiliki scope bisnis yang erat kaitannya dengan risiko, terutama dari segi pemberian kredit, ketika pendapatan perbankan banyak berasal dari kredit yang diberikan kepada nasabah. GCG tidak memiliki pengaruh terhadap nilai perusahaan. Hasil ini menunjukkan adanya ketidaksesuaian antara mayoritas hasil GCG yang diperoleh oleh perbankan dengan adanya masalah internal/eksternal perbankan termasuk fraud di dalam pelaksanaannya. ROA memiliki pengaruh positif terhadap nilai perusahaan. Hasil ini menunjukkan bahwa semakin tinggi earning dapat mengindikasikan prospek perusahaan yang berkualitas baik, sehingga pasar akan merespon positif sinyal tersebut dan nilai perusahaan akan meningkat pula. CAR memiliki pengaruh positif yang signifikan terhadap nilai perusahaan. Hasil tersebut mengindikasikan bahwa modal merupakan faktor penggerak utama pengembangan usaha bisnis, karena modal perusahaan dapat mengembangkan usahana dan kegiatan operasional bank juga dapat berjalan lebih lancar ketika memiliki modal yang cukup.

Keterbatasan penelitian ini adalah tidak digunakannya variabel kumulatif hasil tingkat kesehatan perbankan secara keseluruhan. Penelitian ini juga menggunakan hasil self-assesment yang dilakukan oleh perbankan. Saran untuk penelitian berikutnya, peneliti dapat menambahkan hasil tingkat kesehatan perbankan secara keseluruhan dan menggunakan hasil penilaian pihak eksternal, seperti hasil penilaian GCG dari CGPI. Investor diharapkan untuk lebih perseptif dalam memperhatikan pengelolaan risiko pada suatu bank. Untuk mengimplementasikan GCG, investor sebaiknya tidak hanya melihat hasil akhir peringkat GCG perbankan, tetapi investor juga melihat lebih dalam hasil peniliaian terhadap unsur yang kemungkinan dapat memberikan pengaruh signifikan terhadap nilai perusahaan. Manajemen bank sebaiknya tidak hanya menjadikan GCG sebagai syarat kepatuhan perbankan saja, tetapi GCG menjadi sebuah kebutuhan bagi keberlangsungan usaha. 


\section{DAFTAR REFERENSI}

Abdullah, F. \& Suryanto, L. (2004). Analisis Pengaruh Rasio-Rasio CAMEL sebagai Penilaian Tingkat Kesehatan Bank terhadap Harga Saham Perusahaan Perbankan yang Terdaftar di Bursa Efek Jakarta. Jurnal Studi Manajemen dan Organisasi, $1(2), 1-8$.

Abdulazeez, Y. H., Saif-Alyousfi, Saha, A., \& Rohani, M. (2017). Shareholders Value of Saudi Commercial Banks: A Comparative Evaluation between Islamic and Conventional Bank Using CAMEL Parameters. International Journal of Economics and Financial Issues, 7(1), 97-105.

Astrini, S. F., Biekayanti, G., \& Suhardjanto, D. (2017). Praktik Corporate Governance dan Nilai Perusahaan BUMN di Indonesia. Jurnal Akuntansi, 19(1), 1-30.

Bauer, R., Guenster, N., \& Otten, R. (2004). Empirical Evidence on Corporate Governance in Europe: The Effect on Stcok Return, Firm Value and Performance. Journal of Asset Management, 5(2), 91-104.

Brigham, E. \& Gapenski, L. (2006). Intermediate Financial Management. 7th edition. Sea Harbor Drive: The Dryden Press.

Carillo \& Giovana, M. (2012). The impact of regulation and governance on the risk profile of banks. Dissertation Abstracts International Section A: Humanities and Social Sciences, 73[12-A(E)], 23-34.

Cho, H. J. \& Pucik, V. (2005). Relationship between innovativeness, quality, growth, profitability, and market value. Strategic Management Journal, 26(6), 555-575.

Cholifah, A. N. \& Suhadak. (2017). Analisa Kinerja Keuangan Perbankan Sebelum dan Sesudah Terbentuknya Joint Venture. Jurnal Administrasi Bisnis (JAB), 42(1), $115-124$.

CNN Indonesia (2016). Sejak 2014, OJK Tindak Tegas 108 Kasus Kejahatan Perbankan. CNN Indonesia. Jakarta. Diakses dari https://www.cnnindonesia.com/ekono mi/20161114120838-78-172491/sejak-2014-ojk-tindak-tegas-108-kasus-kejahatan -perbankan.

Ikatan Bankir Indonesia (2018). Supervisi Manajemen Risiko Bank. Jakarta: PT Gramedia Pustaka Utama.

Indiani, L. \& Dewi, S. (2016). Pengaruh Variabel Tingkat Kesehatan Bank terhadap Harga Saham. E-Jurnal Manajemen Unud, 5(5), 2756-2785.

Kontan.co.id. (2019). Rasio Permodalan di Indonesia paling Tinggi se-Asia Tenggara Bahkan Dunia. Kontan.co.id. Jakarta. Diakses dari https://keuangan.kontan.co.id/ news/rasio-permodalan-bank-di-indonesia-paling-tinggi-se-asia-tenggara-bahkandunia?page $=$ all.

Jensen, M. C. \& Warner, J. B. (1988). The Distribution of Power Among Corporate Managers, Shareholders, and Directors. Journal of Financial Economics, III(23), $3-24$.

Fama, E. (1978). The Effect of a Firm Investment and Financing Decision on the Welfare of Its Security Holders. American Economic Review, 68(3), 271-282.

Fauziah, F., Iskandar, R., Paminto, A., \& Ulfah, Y. (2019). Bank Health, the Dividend Policy and Firm Value in Indonesia Banking Sector. International Journal of Humanities and Social Science Invention (IJHSSI), 8(2), 41-49. 
Gieseche, K. (2004). Credit Risk Modelling and Valuation: An Introduction, Credit Risk (2). London: Cornell University.

Garay, U. \& González, M. (2008). Corporate governance and firm value: The case of Venezuela. Corporate Governance: An International Review, 16(3), 194-209.

Gunawan, I. 2016. Pengantar Statistika Inferensial. Jakarta: PT Raja Grafindo Persada.

Hendrayana, P. W. \& Yasa, G. W. (2015). Pengaruh Komponen RGEC pada Perubahan Harga Saham Perusahaan Perbankan. E-Jurnal Akuntansi Universitas Udayana, 10(2), 554-569.

Hidayat, M. (2014). Pengaruh Rasio Kesehatan Perbankan terhadap Nilai Perusahaan (Studi Kasus pada Perbankan yang Terdaftar di Bursa Efek Indonesia). Jurnal Ekonomi dan Informasi Akuntansi (JENIUS), 4(1), 41-47.

Kasmir (2008). Bank dan Lembaga Keuangan Lainnya. Edisi Revisi. Jakarta: PT Rajagrafindo Persada.

Mardiati, U., Nazir, G., \& Putri, R. (2012). Pengaruh Kebijakan Dividen, Kebijakan Hutang, dan Profitabilitas terhadap Nilai Perusahaan Manufaktur yang terdapat di Bursa Efek Indonesia Periode 2005-2010. Jurnal Riset Manajemen Sains Indonesia, 3(1), 1-17.

Murni, S., \& Sabijono. (2018). Peran Kinerja Keuangan dalam Menentukan Nilai Perusahaan. Jurnal Manajemen Bisnis Dan Inovasi, 5(2), 96-107.

Naceur, S. B. \& Goaied. (2008). The Determinants of Commercial Bank Interest Margin and Profitability: Evidence from Tunisia. Frontiers in Finance and Economics, 5(1), 106-130.

Naftali, S. C., Saerang, I. S., \& Tulung, J. E. (2018). Pengaruh Tingkat Kesehatan Bank terhadap Harga Saham Perbankan yang Terdaftar di Bursa Efek Indonesia Periode 2012-2016. Jurnal EMBA, 6(4), 2498-2507.

Nasser, E. \& Djadjang, S. (2005). Analisis Kinerja Bank Pemerintah dan Bank Swasta dengan Rasio CAMEL terhadap Harga Saham. Bulletin Penelitian, 3(3), 217-236.

Tjager, N. (2003). Corporate Governance: Tantangan dan Kesempatan bagi Komunitas Bisnis Indonesia. Jakarta: Prenhallindo.

Retno, R. D. \& Priantinah, D. (2012). Pengaruh Good Corporate Governance dan Pengungkapan CSR terhadap Nilai Perusahaan. Jurnal Nominal, 1(1), 84-103.

O’Sullivan, D. \& McCallig, J. (2012). Customer Satisfaction, Earnings, and Firm Value. European Journal of Marketing, 46(6), 827-843.

Pramana, K. M. \& Artini, L. G. (2016). Analisis Tingkat Kesehatan Bank (Pendekatan RGEC) pada PT Danamon Indonesia, Tbk. E-Jurnal Manajemen Unud, 5(6), 3849-3878.

Renders, A. \& Gaeremynck, A. (2012). Corporate Governance, Principal-Agency Conflicts, and Firm Value in European Listed Companies. Corporate Governance: An International Review, 20(2), 125-143.

Salvatore, D. (2005). Managerial Economics. 5th Edition. Singapore: Thomson Learning.

Saraswathi, Wiksuana, \& Rahyuda (2016). Pengarus Risiko Bisnis, Pertumbuhan Perusahaan dan Struktur Modal terhadap Profitabilitas serta Nilai Perusahaan Manufaktur. E-Jurnal Ekonomi dan Bisnis Universitas Udayana, 3(6), 1729-1756. 
Sasongko, A. S. \& Susilawati, C. E. (2017). Pengaruh Risk Profile, Earnings, dan Capital terhadap Nilai Perusahaan melalui Good Corporate Governance. Jurnal Ilmiah Mahasiswa Manajemen (JUMMA), 6(2), 69-85.

Scharfenaker, E. \& Santos, P. (2015). The Distribution and Regulation of Tobin's $Q$. New York: Elsevier.

Sentausa, S. A. (2009). Perbankan Minta BI Mempermudah Aturan. Diakses pada 1 September 2019 dari kompas.com (25 Maret).

Setyawan, A. W. \& Mawardi, W. (2012). Pengaruh Komponen Risk-based Bank Rating terhadap Harga Saham Perusahaan Perbankan yang Go public di Bursa Efek Indonesia (BEI) Tahun 2008-2011. Diponegoro Business Review, 1(1), 1-11.

Sudiyatno \& Puspitasari (2010). Tobin's Q dan Altman Z-Score sebagai Indikator Pengukuran Kinerja Perusahaan. Jurnal Kajian Akuntansi, 2(1), 9-21.

Sujono \& Soebiantoro (2007). Pengaruh Struktur Kepemilikan Saham (Studi empirik pada perusahaan manufaktur dan non-manufaktur di Bursa Efek Jakarta). Jurnal Manajemen dan Kewirausahaan, 9(1), 3-47.

Sukamulja, S. (2004). Good Corporate Governance di Sektor Keuangan: Dampak GCG terhadap Kinerja Perusahaan (Kasus di Bursa Efek Jakarta). Benefit: Jurnal Manajemen dan Bisnis, 8(1), 1-25.

Sulastiningsih, S. \& Sholihati, R. I. (2018). Pengaruh Kinerja Keuangan dan Corporate Social Responsibility (CSR) terhadap Nilai Perusahaan Perbankan di Bursa Efek Indonesia. Kajian Bisnis, 26(1), 95-111.

Tobin, J. (1967). Tobin's Q Ratio as an Indicator of the Valuation the Company. Journal of Financial Economics, LIII(3), 287-298.

Varaiya, N., Kerin, R. A., \& Weeks, D. (1987). The Relationship between Growth, Profitability, and Firm Value. Strategic Management Journal, 8(5), 487-497.

Wiagustini, N. L. P. \& Permatawati, N. P. (2015). Pengaruh Risiko Bisnis dan Ukuran Perusahaan pada Struktur Modal dan Nilai perusahaan pada Perusahaan Farmasi di Bursa Efek Indonesia. Jurnal Manajemen, Strategi Bisnis dan Kewirausahaan, 9(2), 112-122.

Widati, L. W. (2012). Analisis Pengaruh CAMEL terhadap Kinerja Perusahaan Perbankan yang Go public (Analysis the Influence of CAMEL [CAR, PPAP, DER, BOPO, LDR] toward Performance of Banking Companies in Indonesia). Dinamika Akuntansi, Keuangan dan Perbankan, 1(2), 105-119. 